\title{
KEPUASAN KERJA DITINJAU DARI BEBAN KERJA KARYAWAN YANG BERLATARBELAKANG PENDIDIKAN TIDAK SESUAI DENGAN PEKERJAAN
}

\author{
Zuraida \\ Dosen Program Studi Psikologi \\ Universitas Potensi Utama \\ Jalan K.L. Yos Sudarso Km. 6.5 No. 3 A Tanjung Mulia Medan \\ Surel : zuraidazura1988@,gmail.com
}

\begin{abstract}
Employees who are placed in positions that are not in accordance with educational backgrounds will experience a high workload so that they will feel dissatisfied at work. This study aims to examine the relationship between job satisfaction in terms of the workload of employees whose educational background is not appropriate for their work. Job satisfaction and workload variables are measured using a scale. The subjects of this study were 50 employees who work not according to educational background, with the determination of the sample based on accidental sampling. The analysis technique used in this research is quantitative analysis using Karl Pearson's product moment with the SPSS version 20 for Windows program. Based on the research results, it is known that job satisfaction has a negative relationship with the workload of employees with educational backgrounds that are not suitable for their work. There is a significant negative correlation $(r-0.769$ with sig <0.05) between the variable job satisfaction and the workload of employees whose educational background is not in accordance with their work, namely 0.000 and the significance value is below / smaller 0.05, this means that the lower the job satisfaction, then the higher the workload and vice versa, the higher the job satisfaction, the lower the workload. . Job satisfaction has the most low categories with a contribution of $56 \%$ and the workload at most has a high level category with a contribution of $58 \%$.
\end{abstract}

Keywords: Workload, Job Satisfaction, Employees with No Educational Background In accordance with the work

\begin{abstract}
Abstrak : Karyawan yang ditempatkan pada posisi yang tidak sesuai dengan latar belakang pendidikan akan mengalami beban kerja yang tinggi sehingga akan merasakan ketidakpuasan dalam bekerja. Penelitian ini bertujuan untuk menguji hubungan kepuasan kerja ditinjau dari beban kerja karyawan yang berlatarbelakang pendidikan tidak sesuai dengan pekerjaannya. Variabel kepuasan kerja dan beban kerja diukur dengan menggunakan skala. Subjek penelitian ini berjumlah 50 karyawan yang bekerja tidak sesuai dengan latarbelakang pendidikan, dengan penentuan sampel berdasarkan accidental sampling. Teknik analisis yang digunakan pada penelitian adalah analisis kuantitatif dengan menggunakan product moment karl pearson dengan program SPSS Versi 20 for Windows. Berdasarkan hasil penelitian, diketahui bahwa kepuasan kerja memiliki hubungan negatif dengan beban kerja pada karyawan berlatarbelakang pendidikan tidak sesuai dengan pekerjaannya. Ada korelasi negatif yang signifikan (r-0.769 dengan sig < 0.05) antara variabel kepuasan kerja dengan beban kerja pada karyawan yang latar belakang pendidikan tidak sesuai dengan pekerjaannya yaitu 0.000 dan nilai signifikansinya dibawah/lebih kecil 0.05 , ini berarti bahwa semakin rendah kepuasan kerja maka semakin tinggi beban kerja begitu sebaliknya semakin tinggi kepuasan kerja maka semakin rendah beban kerjanya. Pada kepuasan kerja memiliki kategori paling banyak pada tingkat rendah dengan kontribusi 56\% dan beban kerja paling banyak memiliki kategori tingkat tinggi dengan kontribusi $58 \%$.
\end{abstract}

Kata Kunci : Beban Kerja, Kepuasan Kerja, Karyawan yang Latar Belakang Pendidikan Tidak Sesuai dengan Pekerjaan 


\section{PENDAHULUAN}

Dalam sebuah organisasi Sumber Daya Manusia merupakan aspek terpenting dalam kemajuan organisasi itu sendiri. Sumber Daya Manusia menentukan berhasil atau tidaknya organisasi untuk mencapai tujuan.

Dalam mencapai tujuan organisasi, diperlukan karyawan yang memiliki kemampuan atau skill dibidangnya untuk itu dalam merekrut karyawan, harus sesuai dengan kompetensinya agar karyawan tersebut lebih mudah untuk mengerjakan pekerjaannya.

Namun saat ini masih banyak perusahaan menempatkan karyawan yang latar belakang pendidikannya tidak sesuai dengan pekerjaannya, sehingga karyawannya tersebut mengalami kesulitan untuk mengerjakan tugas pekerjaannya sehingga bisa mengalami ketidakpuasan dalam bekerja (Ardana, 2012)

Menurut Rivai, 2008 menyatakan bahwa kepuasan kerja merupakan penilaian individu atas perasaan puas atau tidak puas dalam bekerja. Selanjutnya menurut Kreitner dan Kinicki (2001) menyatakan bahwa kepuasan kerja merupakan respon perasaan terhadap aspek pekerjaan. Robbins, 2003 menyatakan bahwa kepuasan kerja merupakan sikap seseorang terhadap suatu pekerjaan yang adanya perbedaan terhadap harapan yang diyakini, misalnya jumlah penghargaan yang diterima berbeda dengan jumlah penghargaan yang diyakini seharusnya diterima.

Menurut Kreitner dan Kinicki (2001) ada lima faktor yang mempengaruhi kepuasan kerja yaitu; (1) Adanya pemenuhan kebutuhan (Need fulfillment) dimana kepuasan berdasarkan tingkat karakteristik dari suatu pekerjaan yang dapat memenuhi kebutuhan karyawan tersebut; (2) Perbedaan (Discrepancies), dimana kepuasan dapat terjadi karena memenuhi harapan dari karyawan tersebut. Apabila harapan lebih besar dari yang diterima maka karyawan tersebut merasa tidak puas begitu juga sebalikanya, karyawan akan merasa puas apabila menerimaa sesuai dengan harapannya; (3) Pencapaian nilai (Value attainment) dimana kepuasan karyawan dapat terjadi karena adanya persepsi yang memberikan manfaat atau nilai yang penting; (4) Keadilan (Equity) dimana kepuasan karyawan diperlakukan adil ditempat kerjanya; (5) Komponen genetik (Genetic components), kepuasan kerja merupakan faktor genetik yang membedaan pada masing-masing sifat individu.

Adapun faktor-faktor penentu kepuasan kerja menurut Hariandja (2002) yaitu; (1) Pekerjaan itu sendiri (work it self) dimana pekerjaan membutuhkan keahlian sesuai dengan bidangnya masing-masing. 
Seseorang akan mengalami kepuasan kerja apabila pekerjaannya sesuai dengan bidangnya; (2) Hubungan dengan atasan (supervision), kepuasan kerja akan terjadi apabila karyawan memiliki hubungan yang baik dengan atasannya. Pemimpin yang memiliki ciri transformasional dapat meningkatkan motivasi kerja karyawan dan karyawan memiliki kepuasan kerja dengan pekerjaannya; (3) Teman sekerja (workers), kepuasan kerja dapat terjadi apabila karyawan memiliki hubungan yang baik dengan teman kerjanya; (4) Pomosi (promotion), karyawan akan mengalami kepuasan kerja apabila diberi kesempatan untuk memperoleh peningkatan karir; (5) Gaji atau upah, karyawan akan mengalami kepuasan kerja apabila gajinya dapat memenuhi kehidupan karyawan tersebut dan (6) Lingkungan kerja, seperti lingkungan psikologis dan lingkungan fisik.

Menurut Jewell dan Siegall (dalam Prestawan, 2010) aspek-aspek kepuasan kerja terdiri dari; (a) Aspek psikologis, hal ini menyangkut kejiwaan karyawan yang terdiri dari sikap kerja, minat, bakat dan keterampilan karyawan; (b) Aspek fisik, hal ini berhubungan dengan kondisi fisik lingkungan kerja seperti keadaan ruangan, suhu udara, penerangan dan pertukaran udara. Selain itu kondisi fisik karyawan yang terdiri dari pengaturan waktu kerja, pengaturan waktu istirahat dan kondisi kesehatan karyawan dan umur; (c) Aspek sosial, hal ini berhubungan dengan interaksi antara sesama karyawan, atasan maupun hubungan dengan anggota keluarga; (d) aspek finansial, hal ini berhubungan dengan kesejahteraan karyawan seperti gaji, jaminan sosial, promosi, jaminan sosial maupun fasilitas yang didapatkan.

Adapun jenis-jenis kepuasan kerja menurut Hasibuan (2000) terdiri dari; (a) Kepuasan kerja di dalam pekerjaan, hal ini merupakan kepuasan kerja yang diperoleh dari pujian hasil kerja, perlakuan, penempatan serta suasana lingkungan kerja yang baik; (b) Kepuasan kerja di luar pekerjaan, hal ini karyawan mendapatkan besarnya balas jasa yang diterima dari hasil kerja di luar dari pekerjaannya, ini digunakan untuk mencukupi kebutuhannya; Kepuasan kerja dalam dan luar pekerjaan, adanya keseimbangan antara balas jasa dengan pelaksanaan kerjanya.

Menurut Robbins (2003), ada empat respon karyawan ketika mengalami ketidakpuasan kerja yaitu; (1) Exit, karyawan meninggalkan organisasi, mencari posisi baru atau mengundurkan diri; (2) Voice, karyawan menunjukkan sikap pasif, tetapi optimis menunggu manajemen melakukan suatu yang benar; (3) Kesetiaan (loyalty), karyawan menunggu secara pasif sampai kondisi perusahaan menjadi lebih baik serta membela 
perusahaan dari kritikan di luar; (4) Neglect, karyawan menunjukkan sikap pasif dan membiarkan kondisi perusahaan semakin buruk, mengurangi usaha dan tingkat kesalahan meningkat.

Kepuasan kerja dipengaruhi oleh beban kerja pada karyawan, ketidakpuasan kerja pada karyawan akan menimbulkan dampak negatif seperti motivasi kerja yang rendah (Hamid, 2014). Berdasarkan penelitian Mustapha dan Ghee dalam Dhania (2010) menyatakan bahwa kepuasan kerja dipengaruhi oleh beban kerja. Karyawan akan mengalami kepuasan kerja ketika mereka diberikan beban kerja yang rendah. Selanjutnya menurut Hasibuan (2014) faktor yang mempengaruhi kepuasan kerja karyawan yaitu beban kerja. Beban kerja merupakan kesanggupan karyawan dalam melakukan pekerjaan.

Menurut Irwandy (2007), beban kerja merupakan kegiatan pada suatu pekerjaan dalam jangka waktu tertentu. Selanjutnya beban kerja merupakan perbedaan antara kemampuan pekerja dengan tuntutan pekerjaan (Hancock \& Meshkati, 1988). Selain itu Permendagri No. 12/2008 menyatakan bahwa beban kerja pada suatu organisasi yang mempertimbangkan faktorfaktor jam kerja, jenis pekerjaan maupun latar pendidikan karyawan.

Adapun jenis-jenis beban kerja terdiri dari; (1) Beban kerja fisik, yang merupakan performans kerja tergantung kepada manusia sebagai sumber tenaga. Kelelahan merupakan penurunan kapasitas kerja yang berbeda pada masing-masing individu (Steuerwald et al., 2000); (2) Beban Kerja Mental, pekerjaan bersifat mental sulit diukur aktivitas fisik. Aktivitas mental seperti persepsi, interpretasi, pengambilan keputusan dan proses mengingat informasi (Grandjean \& Kroemer, 1997).

Kerja mental yang tidak baik bisa menyebabkan efek buruk seperti perasaan bosan, lelah dan kurangnya hati-hati dalam melakukan suatu pekerjaan. Hal ini akan berdampak pada penurunan kinerja (Hock \& Joseph, 2019).

Menurut Hancock \& Meshkati, 1988 menyatakan bahwa ada beberapa dampak dari beban kerja berlebihan yaitu; (1) Gejala Fisik, seperti: sakit perut, gangguan pola tidur, sakit kepala, nafsu makan menurun, lesu dll; (2) Gejala Mental, seperti: sulit konsentrasi, mudah marah, putus asa, mudah tersinggung, gelisah dan mudah lupa; (3) Gejala Sosial Perilaku, seperti : menarik diri, menghindar, banyak merokok dan minum alkohol.

Adapun faktor-faktor yang mempengaruhi beban kerja menurut $\mathrm{B}$. Tarwaka (2004) sebagai berikut; (1) Faktor Eksternal, hal ini disebut sebagai stressor 
seperti; (a) tugas-tugas, tugas ada yang bersifat fisik (sarana kerja, kondisi kerja, sikap kerja dan tata ruang kerja), tugas bersifat mental (tanggung jawab pada pekerjaan dan kompleksitas pekerjaan), (b) organisasi kerja (lamanya waktu istirahat, lamanya waktu kerja, sistem pengupahan, tugas dan wewenang, (c) Lingkungan Kerja yang terdiri dari lingkungan kerja fisik (kebisingan, penerangan, mekanis dan getaran), lingkungan kerja kimiawi (pencemaran udara, gas dan debu), lingkungan kerja biologis (parasit, bakteri dan virus) dan lingkungan kerja psikologis (penempatan tenaga kerja); (2) Faktor Internal, faktor ini berasal dari dalam tubuh sebagai reaksi dari faktor beban kerja eksternal. Faktor internal terdiri dari faktor somatis ( umur, ukuran tubuh, jenis kelamin, kondisi kesehatan dan status gizi) dan faktor psikis ( kepercayaan, kepuasan, persepsi motivasi dan keinginan).

Beban kerja dapat diukur dengan beberapa indikator (Hart dan Staveland dalam Astianto, 2014) sebagai berikut; (1) Faktor tuntutan tugas (task demands) merupakan beban kerja yang berdasarkan analisis tugas yang dilakukan oleh tenaga kerja. Perbedaan individu harus diperhitungkan; (2) Usaha atau tenaga (effort), ketika terjadinya peningkatan tuntutan tugas, karyawan mungkin tidak dapat meningkatkan effort; (3)Performansi dimana beban kerja mempunyai performansi yang akan dicapai.

Selanjutnya aspek-aspek beban kerja menurut Ambar (dalam Apriani dkk, 2013) terdiri dari; (a) aspek tugas-tugas, tugas yang dikerjakan apakah sesuai dengan kemampuan dan kompetensi dasar yang dimiliki karyawan. Apabila tidak sesuai dengan kemampuan karyawan tersebut maka akan kesulitan dalam mengerjakan tugas; (b) Aspek seorang atau sekelompok orang mengerjakan tugas-tugas, apakah dalam mengerjakan tugas mendapatkan dukungan dan fasilitas dari lingkungan dengan baik. Apabila mendapatkan dukungan, maka akan mendapatkan hasil yang maksimal dalam bekerja; (c) Aspek waktu, apakah waktu diberikan dalam menyelesaikan tugas, sesuai dengan bobot pekerjaannya. Apabila adanya ketidaksesuaian antara waktu yang diberikan dengan bobot pekerjaan maka karyawan tersebut akan mengalami stress kerja; (d) Aspek keadaan atau kondisi normal, tugas yang dibebankan kepada karyawan apakah sudah sesuai dengan prosedur kerja.

Berdasarkan wawancara dari beberapa karyawan yang ditempatkan tidak sesuai dengan latar belakang pendidikannya ratarata mereka mengalami ketidakpuasan dalam bekerja hal ini dikarenakan tidak sesuai dengan kemampuan dan keahliannya sehingga mereka cepat bosan, mudah lelah, 
kurang termotivasi untuk bekerja, sering salah ketika mengerjakan tugas dan niat mengundurkan diri dari pekerjaannya.

Permasalahan yang terjadi di atas menyebabkan peneliti menjadi tertarik untuk melakukan penelitian dengan judul : Kepuasan Kerja Ditinjau dari Beban Kerja Karyawan yang Berlatar Belakang Pendidikan Tidak Sesuai dengan Pekerjaannya.

\section{METODOLOGI PENELITIAN}

ggunakan metode penelitian yang bersifar kuantitatif dengan teknik korelatif yaitu mencari serta menetapkan adanya korelasi antara variable-variabel penelitian. Dalam hal ini variable penelitian yang dimaksud adalah kepuasan kerja dengan beban kerja.

1. Identifikasi Variabel

Dalam penelitian yang mempelajari hubungan, terdapat variable bebas yang biasanya ditandai dengan symbol $(\mathrm{X})$ dan variable terikat biasa ditandai dengan symbol (Y) (Azwar, 2004). Adapun variable-variabel yang diteliti adalah:
a. Variabel bebas : Kepuasan Kerja
b. Variabel terikat : Beban Kerja

2. Definisi Opreasional

a. Kepuasan Kerja adalah perasaan yang dimiliki individu terhadap pekerjaannya

b. Beban Kerja adalah Perbedaan antara kemampuan pekerja dengan tuntutan pekerjaa $\mathrm{n}$ yang dihadapi.

3. Populasi dan Sampel

Populasi pada penelitian ini yaitu karyawan yang bekerja tidak sesuai dengan latar belakang pendidikannya. Adapun sampel penelitian ini berjumlah 50 karyawan yang bekerja tidak sesuai dengan latar belakang pendidikannya di kota Medan. Teknik penentuan sampel menggunakan accidental sampling. Menurut Sugiyono (2014) menyatakan bahwa accidental sampling merupakan teknik pengambilan sampel berdasarkan kebetulan yang ditemui peneliti dan sesuai dengan sumber data.

4. Metode Pengumpulan Data

Metode pengumpulan data pada penelitian ini yaitu dengan metode skala. Skala kepuasan kerja, yang terdiri dari empat aspek menurut Jewell dan Siegall (dalam Prestawan, 2010) yaitu; (1). Aspek psikologis; (2) Aspek fisik; (3) Aspek Sosial; (4) Aspek Finansial. Skala beban kerja terdiri dari empat aspek menurut Ambar (dalam Apriani dkk, 2013) yaitu; (1) Aspek tugas-tugas; (2) Aspek seorang atau sekelompok orang yang mengerjakan tugas; (3) Aspek waktu; (4) Aspek keadaan atau kondisi normal.

5. Metode Analisis Data

Penelitian ini menggunakan analisis statistik kuantitatif dengan tujuan untuk 
melihat hubungan kepuasan kerja ditinjau dari beban kerja karyawan yang berlatar belakang pendidikan tidak sesuai dengan pekerjaan. Analisis data yang digunakan adalah korelasi produk momen dari Karl Pearson. Produk momen Karl Pearson digunakan untuk melihat hubungan antara dua gejala dengan skala interval (dalam Sugiyono, 2014). Keseluruhan proses analisis data penelitian ini menggunakan bantuan SPSS 20.0 for windows.

\section{HASIL DAN PEMBAHASAN}

1. Validitas dan Reliabitas Kepuasan Kerja

Setelah dilakukan uji validitas untuk kepuasan kerja dengan computer SPSS 20.0 dari 40 item terdapat 33 item yang dinyatakan valid dan 7 item dinyatakan tidak valid/gugur. Item yang valid mempunyai nilai $r$ hitung lebih besar daripada nilai $r$ table yaitu yaitu $(0,3)$.

Dari hasil penghitungan reliabilitas skala kepuasan kerja diperoleh dengan skor alpha sebesar 0,785. Sedangkan reliabilitas skala beban kerja diperoleh dengan skor alpha sebesar 0.824. Butirbutir angket dikatakan reliabel apabila nilai alpha dari setiap item lebih besar dari r table $(0,3)$. Oleh karena itu dari skor yang didapat dari keduanya dapat dikatakan sudah memenuhi standar reliabilitas keduanya dianggap reliable denga taraf signifikan yang diambil 0.05 .

$$
\text { Pengukuran reliabilitas juga }
$$
menggunakan bantuan komputasi SPSS 20.00 for windows program uji keandalan dengan menggunakan teknik alpha cronbanch.

Tabel 1. Uji Reliabilitas Variabel Kepuasan Kerja

\begin{tabular}{|c|c|c|c|c|c|}
\hline No & Variabel & Alpha & R tabel & Ket. & Kriteria \\
\hline 1. & Kepuasan Kerja & 0,785 & 0.3 & Sig $<0,05$ & Reliabel \\
\hline 2. & Beban Kerja & 0,824 & 0.3 & Sig $<0,05$ & Reliabel \\
\hline
\end{tabular}

Dari tabel diatas diketahui bahwa semua variable pernyataan adalah reliabel karena mempunyai nilai alpha lebih besar dari $\mathrm{R}$ tabel $(0,3)$.

\section{Pengujian Hipotesis}

Uji hipotesis menggunakan metode analisis statistik Product Momen Karl Pearson rumus:

Tabel 2. Hubungan Kepuasan Kerja dengan Beban Kerja Correlations

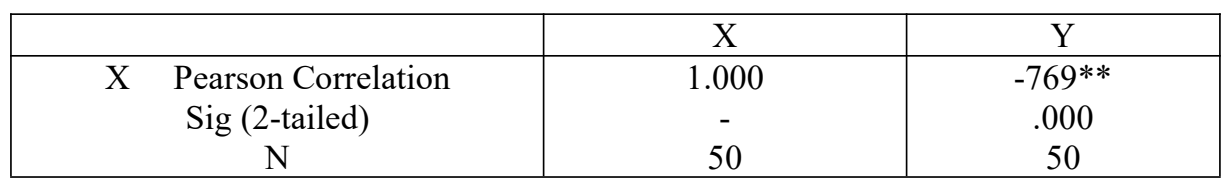




\begin{tabular}{|c|c|c|c|}
\hline $\mathrm{Y}$ & $\begin{array}{l}\text { Pearson Correlation } \\
\text { Sig. (2-tailed) } \\
\text { N }\end{array}$ & $\begin{array}{c}.769 * * \\
.000 \\
50\end{array}$ & $\begin{array}{c}1.000 \\
- \\
120\end{array}$ \\
\hline
\end{tabular}

**Correlation is significant at the 0.01 level

Hipotesis

Ho $=$ Tidak ada hubungan (korelasi) antara dua variable

$\mathrm{Ha}=$ Ada hubungan (korelasi) antara dua Variabel

Ada korelasi negatif yang signifikan (r-0.769; dengan sig $<0.05$ ) antara variable kepuasan kerja dengan variable beban kerja yaitu 0,000 dan nilai signifikansinya dibawah/lebih kecil dari 0,05/0,01 (nilai adalah 0,000).

\section{Standar Deviasi Kepuasan Kerja}

Setelah diolah dengan komputer program SPSS 20.0 for windows. Maka dapat diketahui standar deviasi kepuasan kerja seperti tabel di bawah ini:

Tabel 3. Nilai rata-rata dan Standar Deviasi Variabel Kepuasan Kerja dan Beban Kerja

\begin{tabular}{|c|c|c|}
\hline & X & Y \\
\hline N Valid & 50 & 50 \\
Missing & 0 & 0 \\
Mean & 115.34 & 109.72 \\
Std. Deviation & 16.94 & 12.32 \\
\hline \multicolumn{2}{|c|}{ Sumber data : SPSS setelah diolah }
\end{tabular}

Tabel 4. Proporsi Tingkat Kepuasan Kerja

\begin{tabular}{|c|c|c|}
\hline & Frekuensi & $\%$ \\
\hline$>128.73$ & 9 & 18 \\
$116.69<\mathrm{x}<128.73$ & 13 & 26 \\
$>116.69$ & 28 & 56 \\
\hline & 50 & 100 \\
\hline
\end{tabular}

Sumber data : SPSS setelah diolah

Dari tabel 4 dapat diketahui dari 50 responden yang berpartisipasi terdapat 9 karyawan atau $18 \%$ mempunyai tingkat kepuasan kerja yang tinggi, 13 karyawan atau 26\% mempunyai tingkat kepuasan kerja sedang dan 28 karyawan atau 56\% mempunyai tingkat kepuasan kerja yang rendah. Hal ini ditunjukkan dengan skor $56 \%$ terbesar, dimana skor ini memiliki nilai yang lebih besar dibandingkan dengan dua kategori lainnya yang mendapat $18 \%$ untuk kategori tinggi dan $26 \%$ untuk kategori sedang.

4. Standar Deviasi Beban Kerja

Setelah data diolah dengan komputer program SPSS 20.0 for windows. Maka dapat diketahui Standar Deviasi Y seperti tabel di bawah ini: 
Tabel 5. Nilai Rata-rata dan Standar Deviasi

Variabel Kepuasan Kerja dan Beban Kerja

\begin{tabular}{|cc|c|c|}
\hline & & $\mathrm{X}$ & $\mathrm{Y}$ \\
\hline $\mathrm{N}$ & Valid & 50 & 50 \\
& Missing & 0 & 0 \\
& Mean & 115.34 & 109.72 \\
Std. Deviation & 16.94 & 12.32 \\
\hline
\end{tabular}

Sumber data : SPSS setelah diolah

Tabel 6. Proporsi Tingkat Beban Kerja

\begin{tabular}{|c|c|c|}
\hline & Frekuensi & $\%$ \\
\hline$>86.70$ & 29 & 58 \\
$71<\mathrm{x}<86.70$ & 14 & 28 \\
$<71$ & 7 & 14 \\
& & \\
\hline & 50 & 100 \\
\hline
\end{tabular}

Sumber data : SPSS setelah diolah

Dari tabel 6 dapat dilihat dari 50 responden yang bertisipasi terdapat 29 karyawan atau 58\% kategori beban kerja tinggi, 14 karyawan atau 28\% kategori beban kerja sedang dan 7 karyawan atau $14 \%$ kategori beban kerja rendah. Sehingga dari hasil diatas dapat diketahui tingkat beban kerja ada pada kategori tinggi maka rata-rata karyawan yang memiliki latar belakang pendidikan tidak sesuai dengan pekerjaannya ada pada beban kerja tinggi dengan skor 58\% terbesar, dimana skor ini memiliki nilai yang lebih besar dibandingkan dua kategori lainnya yang mendapat $28 \%$ untuk kategori sedang dan 14\% untuk kategori rendah.
Dalam mencapai tujuan organisasi, diperlukan karyawan yang memiliki kemampuan atau skill dibidangnya untuk itu dalam merekrut karyawan, harus sesuai dengan kompetensinya agar karyawan tersebut lebih mudah untuk mengerjakan pekerjaannya.

Saat ini masih banyak perusahaan menempatkan tidak sesuai dengan latarbelakang pendidikannya sehingga karyawannya tersebut mengalami kesulitan untuk mengerjakan tugas pekerjaannya dan mengalami ketidakpuasan dalam bekerja (Ardana, 2012).

Berdasarkan pendapat para ahli menyatakan bahwa kepuasan kerja merupakan perasaan yang dimiliki individu terhadap pekerjaannya 
Adapun dampak ketidakpuasan kerja menurut Kurniawati, 2006 seperti produktivitas menurun, sering tidak hadir, dan keluarnya tenaga kerja (turn over)

Berdasarkan hasil analisis data, bahwa dari 50 karyawan yang latar belakang pendidikan tidak sesuai dengan pekerjaannya rata-rata mengalami ketidakpuasan kerja. Hal ini bisa dilihat, ada 28 karyawan atau $56 \%$ yang memiliki kepuasan kerja yang rendah, 13 karyawan atau 26\% memiliki kepuasan kerja yang sedang dan ada 9 karyawan atau 18\% mengalami kepuasan kerja yang tinggi. Sehingga dari data bisa dilihat bahwa lebih banyak karyawan yang mengalami ketidakpuasan dalam bekerja karena pekerjannya tidak sesuai dengan latar belakang pendidikan.

Berdasarkan penelitian Mustapha dan Gee dalam Dhania (2010) bahwa kepuasan kerja dipengaruhi oleh beban kerja. Selanjutnya faktor-faktor yang mempengaruhi kepuasan kerja karyawan yaitu beban kerja (Hasibuan, 2014).

Beberapa pendapat para ahli menyatakan bahwa beban kerja merupakan perbedaan antara kemampuan pekerja dengan tuntutan pekerjaan yang dihadapi.

Permendagri No. 12/2008 menyatakan bahwa beban kerja pada suatu organisasi yanag mempertimbangkan faktorfaktor jam kerja, jenis pekerjaan maupun latar pendidikan karyawan.

Berdasarkan hasil analisis data, menunjukkan dari 50 karyawan yang memiliki latar belakang pendidikan berbeda dengan pekerjaannya rata-rata memiliki kategori beban kerja yang tinggi. Seperti dilihat dari hasil analisis data ada 29 karyawan atau 58\% yang memiliki beban kerja yang tinggi, ada 14 karyawan atau 28\% yang memiliki beban kerja yang sedang da nada 7 karyawan atau 14\% yang memiliki beban kerja yang rendah.

Hasil korelasi kepuasan kerja dengan beban kerja menunjukkan sebesar -0.769 dengan $\mathrm{p}=0.000$ hal ini berarti bahwa hubungan antara keduanya adalah negatif dan signifikan karena $\mathrm{p}<0.050$ dikatakan negatif karena hubungan antara kedua variabel yaitu jika variable $\mathrm{X}$-nya rendah maka variabel $\mathrm{Y}$ nya tinggi, dalam hal ini jika diketahui nilai kepuasan kerjanya rendah maka beban kerjanya tinggi, dan hasil tersebut diketahui koefisien determinasinya sebesar $r^{2}=0.769^{2}$ $=0.5913$ yang artinya ada sumbangan efektif $59.1 \%$ variabel kepuasan kerja terhadap beban kerja. Jadi hasil capaian kepuasan kerja dengan beban kerja pada karyawan yang berlatarbelakang pendidikan tidak sesuai dengan pekerjaan tersebut dipengaruhi sebesar $59.13 \%$ sedang sisanya ditentukan oleh faktor-faktor lain.

Berdasarkan uraian di atas 
menunjukkan kepuasan kerja memiliki hubungan terhadap beban kerja. Jadi keduanya mempunyai korelasi yang artinya jika kepuasan kerja rendah maka beban kerja tinggi dan jika kepuasan kerja tinggi maka beban kerja rendah.

\section{SIMPULAN}

Berdasarkan hasil penelitian yang diperoleh, disimpulkan bahwa hipotesis diterima dimana adanya hubungan negatif antara kepuasan kerja dengan beban kerja pada karyawan yang latar belakang pendidikan tidak sesuai dengan pekerjaannya. Artinya, semakin rendah kepuasan kerja maka semakin tinggi beban kerja, dan sebaliknya semakin tinggi kepuasan kerja maka semakin rendah beban kerja. Adapun beberapa saran yang dapat peneliti berikan berdasarkan hasil penelitian yaitu: Bagi perusahaan, sebaiknya merekrut karyawan sesuai dengan kualifikasi pendidikan pada bidang yang dibutuhkan, menempatkan karyawan sesuai dengan keahlian atau kemampuannya agar lebih mudah mengerjakan pekerjaannya. Bagi subjek penelitian, hasil penelitian ini dapat memberikan pengetahuan tentang adanya hubungan kepuasan kerja dengan beban kerja sehingga subjek penelitian dapat mengatasi ketidakpuasan kerja akibat beban kerja yang tinggi. Selanjutnya bagi peneliti berikutnya, diharapkan dapat mengembangkan penelitian dengan menambahkan aspek-aspek lain dari variabel lain dan faktor-faktor lain yang mempengaruhi ketidakpuasan kerja.

\section{DAFTAR RUJUKAN}

Anang Prestawan. 2010. Hubungan Kepuasan Kerja dan Disiplin Kerja dengan Produktivitas Tenaga Kerja Karyawan Asuransi Jiwa Bersama Bumiputera Surakarta. Skipsi Yang Dipublikasikan, Program Studi Psikologi Fakultas Kedokteran Universitas Sebelas Maret.

Anggit Astianto dkk. 2014. Pengaruh Stres Kerja dan Beban Kerja terhadap Kinerja Karyawan PDAM Surabaya. Jurnal Ilmu dan Riset Manajemen

Apriani, D. Nurazi,R \& Praningrum. 2013. Analisis Karakteristik Individu, Komitmen, Organisasi Beban Kerja dan Kinerja Pegawai Dinas Pendidikan Nasional Provinsi Bengkulu. The Manager Review Jurnal Ilmiah Manajemen.

Ardana, 2012, Manajemen Sumber Daya Manusia, Graha Ilmu, Yogyakarta.

Azwar, Saifuddin, Penyusunan Skala Psikologi, Yogyakarta: Pustaka Pelajar, 2004

Departemen Dalam Negeri, PerMen DamNeg No. 12 tahun 2008 tentang Pedoman Analisa Beban Kerja di Lingkungan Departemen Dalam Negeri dan Pemerintah Daerah Jakarta (2008)

Dhania, D.R. (2010). Pengaruh Stres Kerja, Beban Kerja Terhadap Kepuasan Kerja. Jurnal Psikologi Universitas Muria Kudus. Vol. 1, No. 1,

Grandjean, E., Kroemer, 2000. Fitting the Task to the Human. A textbook of 
Occupational Ergonomics. 5 th edition. Piladelphie: Taylor \& Francis.

Hamid, S. (2014). Manajemen Sumber Daya Manusia Lanjutan. Yogyakarta: Deepublish

Hancock, P.A \& Meshkati, N. 1988. "Human Mental Workload". Elsevier Science Publisher B.V : Netherlands.

Hariandja, MT, Efendi, 2002. Manajemen Sumber Daya Manusia: Pengadaan, Pengembangan, Pengkompensasian, dan Peningkatan Produktivitas Pegawai. Grasindo, Jakarta.

Hasibuan, M. 2000. Manajemen Sumber Daya Manusia. Jakarta: PT. BUMI AKSARA

2014. Manajemen Sumber

Daya Manusia. Jakarta: Bumi Aksara.

Irwandy. 2007. Faktor-Faktor yang Berhubungan dengan Beban Kerja Perawat di Unit Rawat Inap RSJ Dadi Makassar Tahun 2005. Magister Administrasi Rumah Sakit. Program Pascasarjana Fakultas Kesehatan Masyarakat. Makasar: Universitas Hasanuddin

Kreitner, Robert. Kinicki, Angelo. 2001. Organizational Behavior. New York: McGraw-Hill Companies, Inc

Rivai, Veithzal dan Ella Juavani Sagala. 2008. Manajemen Sumber Daya Manusia. Jakarta

Robbins, Stephen. P. 2006, Perilaku Organisasi. Jakarta: Gramedia

Sugiyono. (2014). Metode Penelitian Pendidikan Pendekatan Kuantitatif, Kualitatif, dan R\&D. Bandung: Alfabeta.
Tarwaka, Bakri, S. H .A., \& Sudiajeng, L. 2004. Ergonomi Untuk Kesehatan, Keselamatan Kerja \& Produktivitas. Surakarta: Uniba Press 